\title{
“OPTIMIZATION OF GROWTH CONDITION FOR ACIDIC PECTINASE AT SUBMERGED FERMENTATION FROM FRUIT WASTE."
}

\section{VIRENDRA KUMAR PANDEY, SHILPA GAUTAM \& DEEPAK MISHRA*}

Department of Biotechnology, AKS University, Satna

ABSTRACT
Three fungus strains were isolated from compost to make Pectinase. It was determined that cultivation of Talaromyces
aurantiacus, Penicillium oxalate and Aspergillius niger on orange peel substrate under various SSF conditions is a low-
cost alternative to submerged-liquid fermentation when it comes to pectinase production. Optimization of environmental
conditions for Pectinase production was carried out using Pectinase screening agar media (PSAM). Among other factors,
the parameters that concern temperature and pH. The findings show the rise in temperature $25^{\circ} \mathrm{C}$ and pH 4 shows decent
growth. The greatest harvest occurred at orange peels, which yielded $28 m m$ enzymatic properties and yield might be
improved by PSAM optimization.
KEYWORDS: Pectinases, Enzyme, Optimization, Pectinase, Solid State Fermentation

Received: Jun 20, 2021; Accepted: Jul 10, 2021; Published: Jul 16, 2021; Paper Id.: IJASRDEC202114

\section{INTRODUCTION}

The processing of citrus fruits generates over 34 million tonnes of citrus residue (peel, seeds) per year[Huang et.al., (2010), Martín et.al., (2010), Anwar et.al., (2008)]. Many environmental issues are caused by a small fraction of these residues being applied in the diet of monogastric animals. While citrus peel is an essential and affordable raw material for producing enzymes, most notably Pectinase, via fermentation, it may also be used to prepare citrus oil, which can then be used for a variety of purposes[Palit et.al., (2001)]. The media that is used in this experiment provides all of the nutrients required for microorganism development, and numerous key metabolites, including enzymes, have been examined in regard to their synthesis. Extraction, clarity, and cloud stabilization of fruit juices, in degumming and retting of natural fibers are all assisted by Pectinases, which catalyze the breakdown of pectin (polygalacturonic acid) to galacturonic acid residues[Kumar et.al., (2010) Mamma et.al., (2008) Tari et.al., (2007), Botella et.al., (2007), Kuhad et.al., (2004),De Gregorio et.al., (2002), Silva et.al., (2002)].

Using pectinolytic enzymes, different industrial processes may be handled. Because these enzymes are effective at decreasing the viscosity of liquors during the clarifying process, they are employed widely in the food and drink industries, mainly in juice clarity [Oszmianski et.al., (2011), Pedrolli et.al., (2008)]. However, prior studies show that PG is produced by Solid State Fermentation using agro-industrial wastes and other microorganisms. Consider the metabolites generated in an Solid State Fermentation to be trapped in a solid matrix, requiring them to be removed via a liquid-liquid extraction or leaching. Since this is the first stage in every recovery and purification procedure for any desired metabolite created by Solid State Fermentation, this is also the first step in any process like that.

Due to their low cost, significant enzyme production capacity, and affordable cost, orange peel (pectin waste) is utilized as a substrate rather as synthetic cellulose, resulting in reduced manufacturing costs [Sharma et.al., 
2004]. The reduction in cost makes the Pectinase manufacturing process much more economically feasible. A serious problem has to be solved. As in the case of fermentation, which harnesses pectin enzymes to help manufacturers reduce waste and pollution, 2 of 9 with the residue for complete use of pectin resources and to keep pollutants out of the environment [He et.al, (2004)].

Varying the only independent variable while maintaining the others at a fixed level is the typical technique for improving enzyme production by utilising a "one variable at a time" strategy. By utilising this method, it is tedious and time-consuming as it necessitates the use of a huge number of variables, and it does not factor in how various variables interact [Kumari et.al., (2008)]. Statistics can be used as an alternate and more efficient technique. In PSAM, a thorough factorial search of all the factors is made in order to find all of the simultaneous, systematic, and efficient variation. While statistical optimization makes it possible to quickly and thoroughly test a whole large-scale experiment, it also reflects the contributions of each of the components. The implementation of PSAM for media and culture conditions has previously proved to be effective when used to maximise productivity in the synthesis of primary and secondary metabolites, such as amino acids, ethanol, and enzymes.

This research was conducted to improve the production of an acidic pectinase from Fungal spp., as well as to explore industrial possibilities for the enzyme, in light of the newly-found fact that pectinases has industrial uses. Using Central Composite Design and PSAM, the factors that were shown to be essential to optimising enzyme production in submerged fermentation were optimised, and hence, increased.

\section{MATERIALS AND METHODS}

\section{Substrates and Chemicals}

Orange peels taken from the market in Satna, Madhya Pradesh, India were found to contain a variety of agro-waste residues. A supply of fine-ground substrates was dried in the hot air oven at 60 degrees Celsius (C) for 48 hours, ground, and stored in sterile containers until use. This study used all Hi-Media Limited, SRL Pvt. Limited-made chemicals.

\section{Source of Fungal Inoculums}

A fungus species that produces pectinase was isolated from Malt extract agar medium (which contains plenty of pectin) and cultured at $4{ }^{\circ} \mathrm{C}$.

\section{Solid State Fermentation}

Dried citrus peel (which had a $75 \%$ average particle size ranging from 0.8 to $2.0 \mathrm{~mm}$, and the other $25 \%$ had a range between 2.0 and $3.0 \mathrm{~mm}$ ) was mixed with the following substances, as a dry substance, which supplies the following elements: Ammonium nitrate $(0.43 \%)$; sodium sulphate $(0.021 \%)$; magnesium sulphate $(7.7 \mathrm{H} 2 \mathrm{O}, 0.077 \%)$; zinc sulphate $(0.042 \%)$; potassium chloride $(0.162 \%)$; and calcium hydroxide $(0.011 \%)$. Adding water to increase the percentage of initial humidity got us to 60 percent. One part inoculant was used in a tenfold (1:10) dilution of moist solid medium. The flask was $250 \mathrm{~mL}$ in size and the neck was broad, and therefore was appropriate for fermentations. Cultures were left to develop at their own pace without being agitated. Every experiment was performed three times.

\section{Polygalacturonase (PG) activity}

The D-N-Salicylsalicylic (DNS) assay was used to determine the level of reducing sugars present in the test sample. Pectin was a simple sugar produced following pectin breakdown, and galacturonic acid (Sigma) was regarded as a simple sugar to 
that particular study[Breed et.al., (1947)]. When diluted, an enzyme solution had $0.1 \mathrm{~mL}$ of the enzyme solution added to $0.9 \mathrm{~mL}$ of $0.5 \%(\mathrm{w} / \mathrm{v})$ pectin (Sigma) in $0.1 \mathrm{M}$ citrate buffer $(\mathrm{pH} 4.0)$. The reaction was allowed to incubate at $50{ }^{\circ} \mathrm{C}$ for 15 minutes, after which it was heated to boiling water for 5 minutes. To each sample, a total of $5 \mathrm{~mL}$ of distilled water was added. Samples were examined for absorbance at $540 \mathrm{~nm}$. The activity of a single enzyme that catalyses the conversion of D-galacturonic acid to D-galactose is defined as $1 \mathrm{~mol}$ of D-galacturonic acid released per minute at $50^{\circ} \mathrm{C}$ and $\mathrm{pH} 4.0$ [Rodríguez-Fernández et.al., (2011)].

\section{Optimization Design}

Various microbial strains, media, and growth factors were systematically and individually varied. 3 strains had the ability to degrade pectin Talaromyces aurantiacus, Penicillium oxalate, and Aspergillius niger, all performed within a temperature range of 20 to 35 degrees Celsius with a pH of 2 to 5 at substrate such orange peel, banana peel, sugarcane bagasse, and pineapple peel.

\section{Result and Discussion}

Three strains of fungus were selected following the first screening, where each was shown to have pectinase activity. This demonstrates the outcomes of the studies on $\mathrm{pH}$ and temperature optimization, as well as variable substrate optimization.

\section{Temperature Optimization Results}

Graph for Temperature optimization and shows that Acidic Pectinase enzyme activity is highest at $25^{\circ} \mathrm{C}$.

Table 1: Culture Optimization and Enzyme Characterization (Temperature)

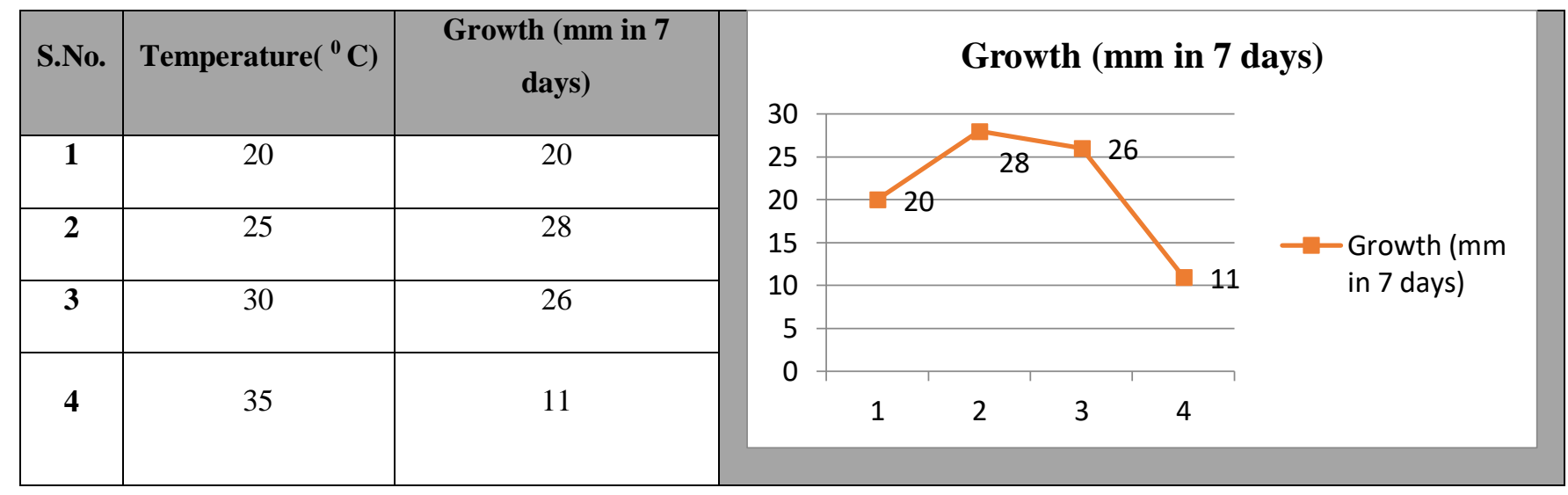


Table 2: Culture Optimization and Enzyme Characterization (pH)

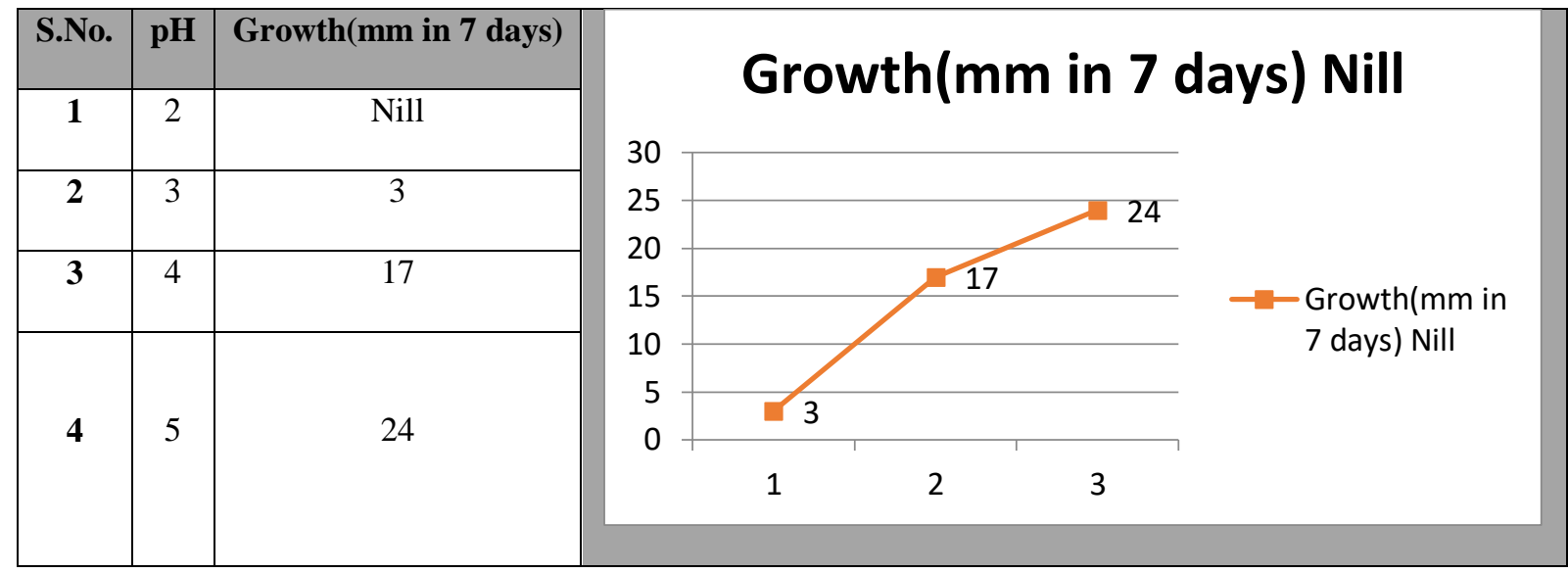

Table 3: Culture Optimization and Enzyme Characterization (Substrate)

\begin{tabular}{|c|l|c|}
\hline S.No. & Nutrients(Fruit Waste) & Growth (mm in 7 days) \\
\hline $\mathbf{1}$ & Orange peel & 20 \\
\hline $\mathbf{2}$ & Sugarcane baggases & 8 \\
\hline $\mathbf{3}$ & Banana peel & 3 \\
\hline $\mathbf{4}$ & Apple peel & Nill \\
\hline
\end{tabular}

\section{CONCLUSIONS}

The research was done to improve enzyme manufacturing conditions. As a result, costs for Acidic Pectinase are increasing, resulting in increased fruit juice clearance and a wider range of industrial uses. Thus, as a result, the fact that Pectinase increases in production at $\mathrm{pH} 4,25^{\circ} \mathrm{C}$, and with orange peels.

\section{REFERENCES}

1. Oszmianski, J.; Wojdyto, A.; Kolniak, J. Effect of pectinase treatment on extraction of antioxidant phenolsfrom pomace, for the production of pure enriched cloudy apple juices. Food Chem. 2011, 127, 623-631.

2. Pedrolli, D.B.; Gomes, E.; Monti, R.; Cano-Carmona, E. Studies on productivity and characterization of polygalacturonase from Aspergillusgiganteus submerged culture using citrus pectin and orange waste. Appl. Biochem. Biotechnol. 2008, 144, $191-200$

3. Kumari, S.K.; Babu, I.S.; Rao, G.H. Process optimization for citric acid production from raw glycerol using response surface methodology. Indian J. Biotechnol. 2008, 7, 496-501.

4. Breed, R.S.; Murray, E.G.D.; Smith, N.R. Bergey's Manual of Determinative Bacteriology, 7th ed.; The Williams and Wilkins Co., American Society of Microbiology: Baltimore, MD, USA, 1957.

5. Rodríguez-Fernández, D.E.; Rodríguez-León, J.A.; de Carvalho, J.C.; Sturm, W.; Soccol, C.R. The behavior of kinetic parameters in production of pectinase and xylanase by solid-state fermentation. Bioresour. Technol. 2011, 102, $10657-10662$.

6. Huang, Y.S.; Ho, S.C. Polymethoxy flavones are responsible for the anti-inflammatory activity of citrus fruit peel. Food Chem. 2010, 119, 868-873.

7. Martín, M.A.; Siles, J.A.; Chica, A.F.; Martín, A. Biomethanization of orange peel waste. Bioresour. Technol. 2010, 101, 8993-8999. 
8. Anwar, F.; Naseer, R.; Bhanger, M.I.; Ashraf, S.; Talpur, F.N.; Aladedunye, F.A. Physico-chemicalcharacteristics of citrus seeds and seed oils from Pakistan. J. Am. Oil Chem. Soc. 2008, 85, 321-330.

9. Palit, S.; Banerjee, R. Optimization of extraction parameters for recovery of _- amylase from the fermentedbran of Bacillus circulans GRS313. Braz. Arch. Biol. Technol. 2001, 44, 107-111.

10. Kumar, Y.S.; Varakumar, S.; Reddy, O.V.S. Production and optimization of polygalacturonase from mango (Mangiferaindica L.) peel using Fusariummoniliforme in solid state fermentation. World J. Microbiol. Biotechnol. 2010, 26, 1973-1980.

11. Mamma, D.; Kourtoglou, E.; Christakopoulos, P. Fungal multienzyme production on industrial by-products of the citrusprocessing industry. Bioresour. Technol. 2008, 99, 2373-2383.

12. Tari, C.; Gögus, N.; Tokatli, F. Optimization of biomass, pellet size and polygalacturonase production by Aspergillussojae ATCC 20235 using response surface methodology. Enzym. Microb. Technol. 2007, 40, 1108-1116.

13. Botella, C.; Diaz, A.; de Ory, I.; Webb, C.; Blandino, A. Xylanase and pectinase production by Aspergillus awamori on grape pomace in solid state fermentation. Process Biochem. 2007, 42, 98-101.

14. Kuhad, R.C.; Kapoor, M.; Rustagi, R. Enhanced production of an alkaline pectinase from Streptomyces sp.RCK-SC by wholecell immobilization and solid-state cultivation. World J. Microbiol. Biotechnol. 2004, 20,257-263.

15. De Gregorio, A.; Mandalari, G.; Arena, N.; Nucita, F.; Tripodo, M.M. SCP and crude pectinase production by slurry-state fermentation of lemon pulps. Bioresour. Technol. 2002, 83, 89-94.

16. Silva, D.; Martins, E.S.; Silva, R.; Gomes, E. Pectinase production by Penicilliumviridicatum rfc3 by solid state fermentation using agricultural wastes and agro-industrial by-products. Braz. J. Microbiol. 2002, 33, 318-324.

17. Sharma, D.C.; Satyanarayana, T. Production and application of pectinolytic enzymes of Sporotrichum thermophile and Bacillus pumilus. In Biotechnological Approaches for Sustainable Development; Reddy, M.S., Khanna, S., Eds.; Allied Publishers Pvt. Ltd: New Delhi, India, 2004; pp. 164-169.

18. He, G.Q.; Kong, Q.; Ding, L.X. Response surface methodology for optimizing the fermentation medium of Clostridium butyricum. Lett. Appl. Microbiol. 2004, 39, 363-368.

19. AL-ASADY, AMAL KADHIM GHADBAN. "Optimization of a-amylase production from a local isolate of Bacillus licheniformis and characterization of purified enzyme." International Journal of Agricultural Science and Research 6.2 :301312.

20. Doshi, Amrita, and Anjali Karolia. "Optimization of enzyme treatment for banana fiber." International Journal of Textile and Fashion Technology (IJTFT) $6.2: 1-8$.

21. Parameswari, M. "Textile and Dye Industry Effluent, Sludge and Amendments on Dehydrogenase and Phosphatase Activity of Soil under Sunflower Crop." International Journal of Applied and Natural Sciences (IJANS) 3.2 :45-52.

22. Winata, A. A., H. S. Yuwono, and P. Hapsari. "Correlation between MMP-1 Responses and Epithelialization of Acute Staphylococcus Aureus Infected Wounds Treated by Coffee Powder, Saline Gauze, and Hydrocolloid." International Journal of General Medicine and Pharmacy 6.5 :31-38. 
